\title{
Higher glucose level can enhance the H. pylori adhesion and virulence related with type IV secretion system in AGS cells
}

Shew-Meei Sheu ${ }^{1,2}$, Hsin Cheng ${ }^{2}$, Cheng-Ye Kao ${ }^{1,4}$, Yao-Jong Yang ${ }^{3}$, Jiunn-Jong Wu ${ }^{1,4}$ and Bor-Shyang Sheu ${ }^{1,2,5^{*}}$

\begin{abstract}
Background: Hyperglycemia increases the risk of gastric cancer in H. pylori-infected patients. High glucose could increase endothelial permeability and cancer-associated signaling. These suggest high glucose may affect $\mathrm{H}$. pylori or its infected status.

We used two strains to investigate whether $H$. pylori growth, viability, adhesion and CagA-phosphorylation level in the infected-AGS cells were influenced by glucose concentration (100, 150, and $200 \mathrm{mg} / \mathrm{dL}$ ).

Results: The growth curves of both strains in $200 \mathrm{mg} / \mathrm{dL}$ of glucose were maintained at the highest optimal density after $48 \mathrm{~h}$ and the best viability of both strains were retained in the same glucose condition at $72 \mathrm{~h}$. Furthermore, adhesion enhancement of $\mathrm{H}$. pylori was significantly higher in $200 \mathrm{mg} / \mathrm{dL}$ of glucose as compared to that in 100 and $150 \mathrm{mg} / \mathrm{dL}(p<0.05)$. CagA protein also increased in higher glucose condition. The cell-associated CagA and phosphorylated-CagA was significantly increased in 150 and $200 \mathrm{mg} / \mathrm{dL}$ of glucose concentrations as compared to that of $100 \mathrm{mg} / \mathrm{dL}(\mathrm{p}<0.05)$, which were found to be dose-dependent.

Conclusion: Higher glucose could maintain H. pylori growth and viability after 48 h. H. pylori adhesion and CagA increased to further facilitate the enhancement of cell-associated CagA and phosphorylated CagA in higher glucose conditions.
\end{abstract}

Keywords: Glucose, Helicobacter pylori, CagA

\section{Background}

Helicobacter pylori infection in the human stomach causes chronic inflammation, leading to peptic ulcers and gastric malignancy [1-3]. Other cofactors may be involved in the H. pylori related gastric carcinogenesis, because not all H. pylori-infected patients develop gastric cancer. Some reports have shown that there is a significantly higher prevalence of $H$. pylori infection in patients with type 2 diabetes mellitus (DM), who also have a lower eradication rate [4-6]. In particular, a higher fasting plasma glucose level in $H$. pylori-seropositive patients may correlate with an increased risk of gastric cancer up to a nearly 3.5-4.2 fold increase [7]. These data suggest that hyperglycemia

\footnotetext{
*Correspondence: sheubs@mail.ncku.edu.tw

'Institute of Basic Medical Sciences, College of Medicine, National

Cheng-Kung University, Tainan, Taiwan

2Department of Medicine, College of Medicine, National Cheng-Kung University,

Tainan, Taiwan

Full list of author information is available at the end of the article
}

may be an important cofactor to influence $H$. pylori mediated gastric carcinogenesis [8].

To establish H. pylori colonization and chronic inflammation at the gastric epithelium, adherence can serve as the first step of infection and then deliver effectors to induce inflammation [9-11]. The major adhesion, blood group antigen binding adhesin (BabA), binds to Lewis $\mathrm{b}$ (Leb) and related $\mathrm{ABO}$ antigens to initiate bacterial adhesion and stimulate IL-8 secretion [12-14]. Moreover, cytotoxin-associated gene A antigen (CagA), an onco-protein, is translocated into gastric epithelial cell through type IV secretion system of H. pylori [15-18]. The tyrosine in the EPIYA motif of CagA C-terminal could be phosphorylated [19] and thus can change the cell morphology, increase cell motility, and promote cell proliferation [20-23].

Hyperglycemia leads into an increased risk of gastric cancer in the H. pylori-infected patients [7]. Moreover, high glucose can enhance cancer-associated Wnt/ $\beta$ - 
catenin signaling [24]. These results suggest a link between hyperglycemia, $H$. pylori and gastric cancer. High glucose could also increase endothelial permeability and altered basement membrane composition and structure [25,26], which may make $H$. pylori infection occur in a high glucose condition, such as the patients with hyperglycemia. Therefore, it is worth investigating whether or not glucose can influence the expressions of $\mathrm{H}$. pylori virulence to promote carcinogenesis. This study is original to illustrate that higher glucose concentrations can promote bacterial growth of $\mathrm{H}$. pylori isolates, facilitate bacterial adhesion to gastric epithelial cells, and up-regulate the expression of CagA protein to facilitate more virulence related to type IV secretion system.

\section{Methods}

\section{Assessment to the $H$. pylori growth under different glucose levels}

Strain 199 and ATCC 43504 were purchased from ATCC and stored at $-70^{\circ} \mathrm{C}$ in $\mathrm{BHI}$ with $30 \%$ glycerol until testing was conducted. H. pylori strains were cultured on CDC anaerobic blood agar (BBL, Microbiology Systems, Cockeysville, MD, USA). When determining growth curve, $H$. pylori strains were cultured in Brucella broth containing $10 \%$ horse serum and different concentration of glucose $(100,150,200 \mathrm{mg} / \mathrm{dL})$ at $37^{\circ} \mathrm{C}$ for 3 days in a microaerophilic conditions, with shaking at 50-52 rpm. The optical density (OD) at $600 \mathrm{~nm}$ of bacterial growth was evaluated at 20,48 , and $72 \mathrm{~h}$. Bacterial viability was detected at 48 and $72 \mathrm{~h}$ of growth curve and analyzed by serious dilution to count colony formation unit (CFU) per ml.

\section{Co-culture of $H$. pylori \& AGS cells under different glucose levels}

The human gastric adenocarcinoma cell line, AGS, was purchased from Food Industry Research and Development Institute in Taiwan and was grown in the cell medium, Ham's F-12 medium (GIBCO BRL, Grand Island, NY) containing 10\% FCS. The cells were sub-cultured every second to third day. To conduct the $H$. pylori adhesion assays in AGS cells, the AGS cells $\left(5.5 \times 10^{5} /\right.$ well $)$ were seeded to one well of 6-well plates for $22 \mathrm{~h}$ and then replaced the cell medium to cell medium supplemented with different concentrations $(100,150,200 \mathrm{mg} / \mathrm{dL})$ of glucose for 3.5-4 h. After washing with the mixture of F-12 medium and $1 \times$ PBS $(1: 1)$ to the AGS cells cultivated in medium with specific concentrations of glucose, the serum-free F-12 medium (SFM) with the same glucose concentration were added again. As well, the both $H$. pylori strain 599 and 43504 were cultured for 20 hours in Brucella broth including 10\% horse serum under three glucose concentrations, including 100, 150, $200 \mathrm{mg} / \mathrm{dL}$, respectively. The bacteria shall be washed twice with the SFM containing the same glucose contraction before adding to cells. After washing, these bacterial suspensions in the SFM will be then applying to the well that contained AGS cells with the same concentration of glucose treatment at Multiplicity of infection (MOI) as 30-40. In each glucose level, there should be co-cultured with H. pylori and AGS cells for two wells, including the first one for adhesion assay, the second one for the detection of CagA phosphorylation. The first well was washed three times with the SFM 30 min later to detect bacterial adhesion and the second well was incubated for $4 \mathrm{~h}$ to detect CagA phosphorylation.

\section{H. pylori adhesion assay to AGS cells under different glucose levels}

In order to calculate the percentage of bacterial adhesion, lysate of $H$. pylori adhering to AGS cells and the original suspension of $H$. pylori adding to adhesion assays were seriously diluted respectively and grown on CDC plates to count bacterial CFU. The adhesion CFU divided by the original CFU is the adhesion percentage of H. pylori.

\section{Western blotting for detection H. pylori BabA, CagA and CagA phosphorylation}

The bacterial suspension adding to detect adhesion ability under different glucose concentration was also collected to determine protein concentration. An equal amount of bacterial protein $(1.5-2 \mu \mathrm{g})$ was used to detect the expression of BabA and CagA by performing western blotting. Moreover, the well of co-cultured H. pylori and AGS cells incubated for $4 \mathrm{~h}$ was washed 3 times to collect cell lysates for detection of CagA and CagA phosphorylation. Antibodies $(\mathrm{Ab})$ used in western blotting included the anti-BabA as applied in our previous report [27], anti-phospho-tyrosine (PY99) (Santa Cruz Biotechnology), anti-CagA (Santa Cruz Biotechnology) and anti-beta Actin (Minipore) Abs.

\section{Statistics}

The statistical analysis was performed by using a paired $t$ test. The differences were considered to be significant at $p<0.05$.

\section{Results}

Effect of glucose level on H. pylori growth curve and viability

Strain 199 and 43504, grown in broth containing three concentrations of glucose $(100,150,200 \mathrm{mg} / \mathrm{dL})$, were applied to detect the growth curve during $72 \mathrm{~h}$ (Figure 1A and B). Optical density of strain $J 99$ at $200 \mathrm{mg} / \mathrm{dL}$ were kept on increasing at $72 \mathrm{~h}$, however, OD value was decreased in 100 and $150 \mathrm{mg} / \mathrm{dL}$ of glucose conditions at the same time (Figure 1A). The significant difference between 3 growth curves of strain 599 was observed at 48 h (J99-100 vs. J99-150, $\mathrm{p}<0.05$; J99-100 vs. J99-200, 

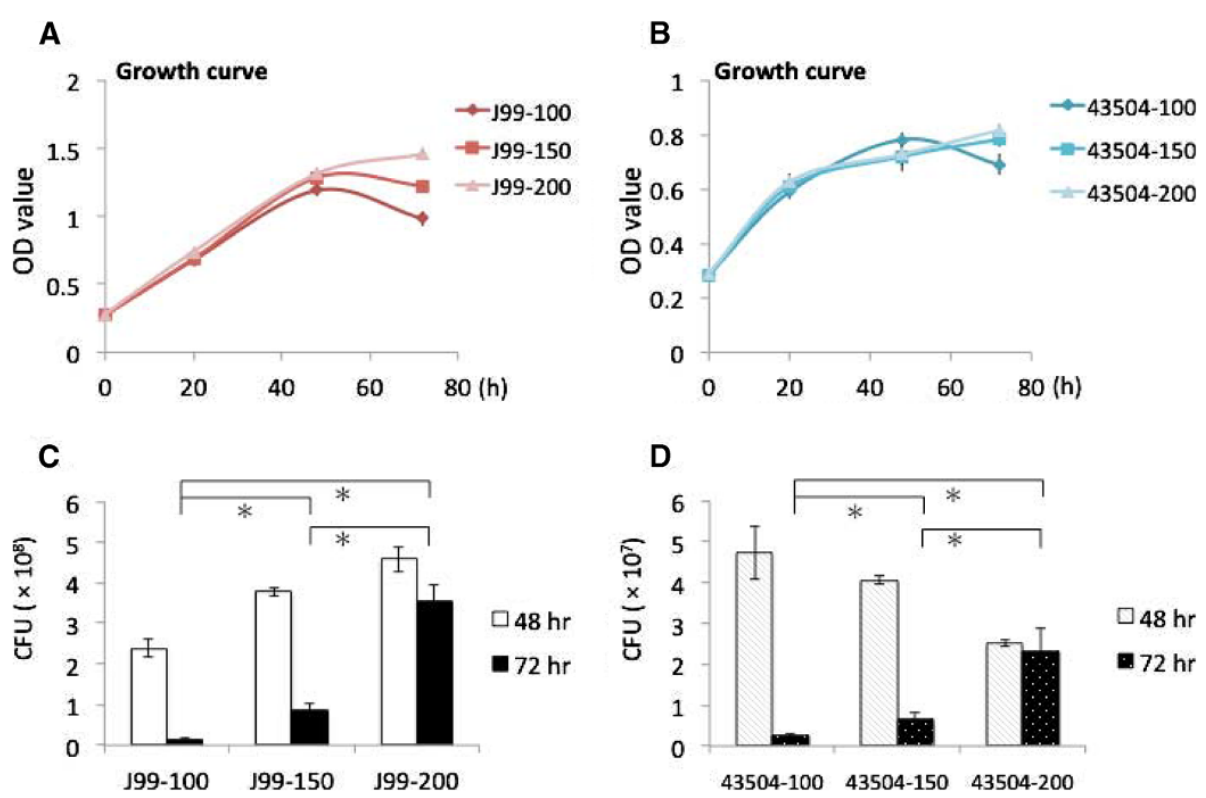

Figure 1 H. pylori growth and viability was increased under higher glucose level after $\mathbf{4 8}$ hr. (A, B) Strain J99 and 43504 grew in Brucella broth containing 10\% horse serum and different level of glucose (100, 150, $200 \mathrm{mg} / \mathrm{dL})$. The optical density (OD) at $600 \mathrm{~nm}$ of bacterial growth was evaluated during 72 h. (C, D) Colony formation unit (CFU) of strain $J 99$ and 43504 was determined at growth curve of 48 and 72 h. * indicated $\mathrm{p}<0.05$ (paired $t$ test).

$\mathrm{p}<0.05$; J99-150 vs. J99-200, p > 0.05) and $72 \mathrm{~h}(\mathrm{~J} 99-100$ vs. J99-150, $\mathrm{p}=0.05$; J99-100 vs. J99-200, $\mathrm{p}<0.05$; J99-150 vs. J99-200, $\mathrm{p}<0.05)$. Growth of strain 43504 in higher glucose concentrations (150 and $200 \mathrm{mg} / \mathrm{dL}$ ) had the trend of higher optimal density, as compared to low glucose $(100 \mathrm{mg} / \mathrm{dL})$, except $48 \mathrm{~h}$. Besides strain 43504 at $48 \mathrm{~h}, H$. pylori viability was increased by the increasing glucose concentration (Figure $1 \mathrm{C}$ and D). Especially at $72 \mathrm{~h}$, the viability of two strains cultured in 150 and $200 \mathrm{mg} / \mathrm{dL}$ were consistently increased as compared to that in $100 \mathrm{mg} / \mathrm{dL}(\mathrm{p}<0.05)$. Viability showed $3-4$ fold increases in $200 \mathrm{mg} / \mathrm{dL}$ as compared to that in $150 \mathrm{mg} / \mathrm{dL}$ $(\mathrm{p}<0.05)$.

Higher glucose level treated to $H$. pylori isolates enhance the bacterial adhesion

With the treatment of $200 \mathrm{mg} / \mathrm{dL}$ of glucose to $H$. pylori and AGS cells, the adhesion ability of strain $J 99$ and 43504 was significantly enhanced as compared with that of 150 and $100 \mathrm{mg} / \mathrm{dL}$ of glucose treatment (Figure 2A and B). In order to test whether cellular factors play some role in adhesion enhancement, strain J99 and 43504 growth in 100, 150, and $200 \mathrm{mg} / \mathrm{dL}$ of glucose adhered to AGS cells with pretreatment of with contrary concentration (200,150, $100 \mathrm{mg} / \mathrm{dL}$ ), respectively (shown in Figure 2C and D). Nevertheless, the adhesion abilities within each strain were similarly disclosed with an increasing trend based on the glucose level treated to the bacteria (strain J99 on Figure 2A and C; strain 43504 on Figure $2 \mathrm{~B}$ and $\mathrm{D})$.

To check that the effect of glucose on increasing bacterial growth and adhesion not due to change osmolality, we used L-glucose without biological activity to assess the same experiment. Our data confirmed L-glucose did not increase OD value at $72 \mathrm{~h}$. Additionally, the adhesion ability of both strains in either 150 or $200 \mathrm{mg} / \mathrm{dL}$ of glucose were similar to that in $100 \mathrm{mg} / \mathrm{dL}$ (data not shown).

\section{Effect of glucose level on H. pylori type IV secretion system-related virulence}

BabA expression of $H$. pylori, in either strain J99 or 43504, was similar among three glucose concentrations including 100, 150, and $200 \mathrm{mg} / \mathrm{dL}$. However, for either one isolates, the expression of CagA can be increased as the bacteria exposed to glucose concentration which was raised from 100 to $200 \mathrm{mg} / \mathrm{dL}$ (Figure 3A). When H. pylori infected to AGS cells, the cell-associated CagA of strain J99 presented with a significant stepwise increase by the glucose treatment in level up to 150 and $200 \mathrm{mg} / \mathrm{dL}(\mathrm{p}<0.05)$, as compared to the glucose treatment as $100 \mathrm{mg} / \mathrm{dL}$ (Figure 3B). Also in Figure 3B, the cell-associated CagA of strain 43504 had the similar scenario to that of strain J99. Strain 43504 had a significantly increased trend of phosphorylated CagA levels ranking in order parallel to the elevation of glucose levels from 100, 150, and up to $200 \mathrm{mg} / \mathrm{dL}(\mathrm{p}<0.05$, Figure 3B). 

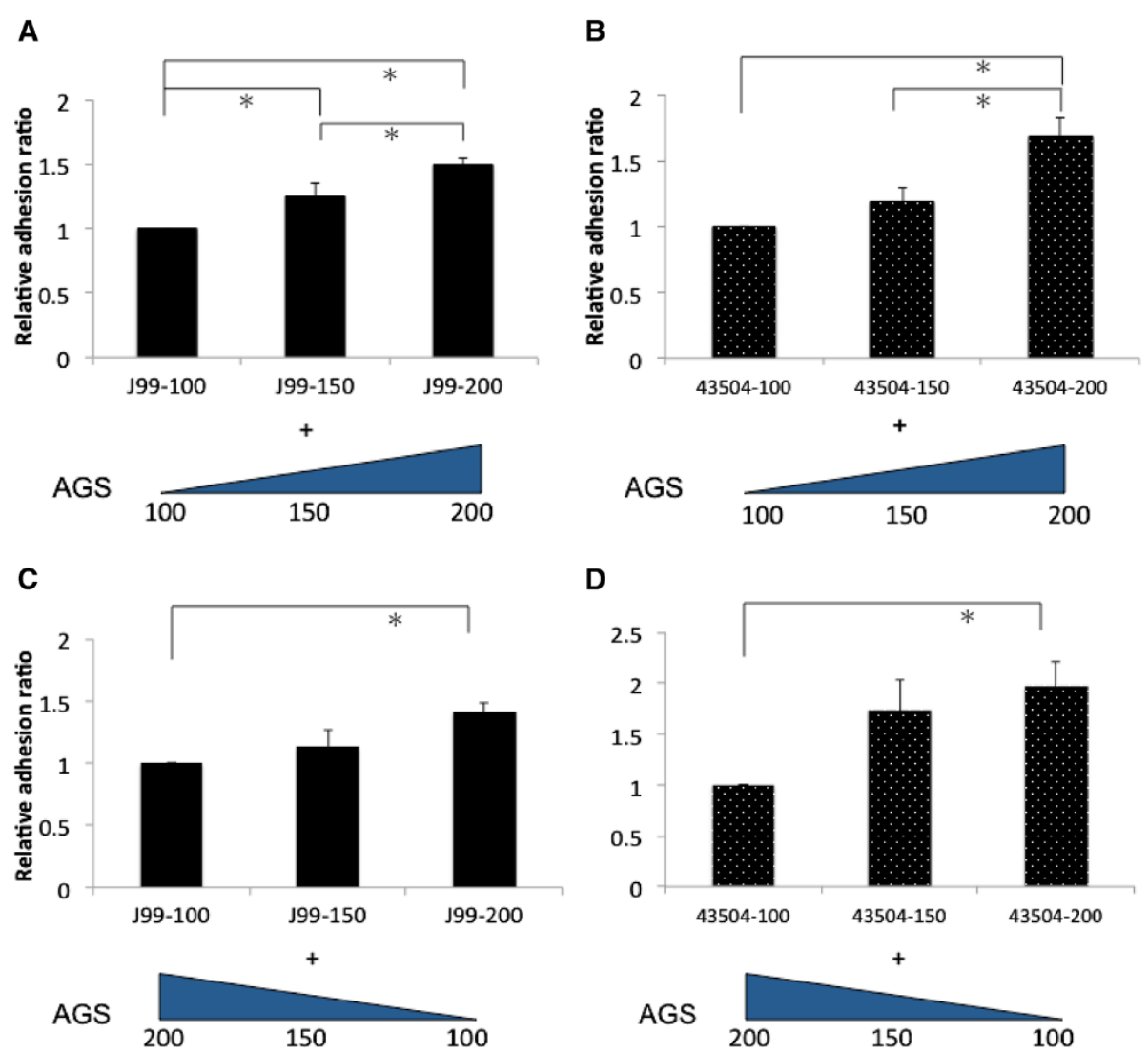

Figure 2 Adhesion ability of $\mathbf{H}$. pylori increased under the treatment of higher glucose concentration. Strain J99 and 43504 growth in different level of glucose $(100,150,200 \mathrm{mg} / \mathrm{dL})$ was added to AGS cells with the pretreatment of the same glucose concentration (A, B) or the pretreatment of contrary concentration (200,150, $100 \mathrm{mg} / \mathrm{dL}$ ) (C, D). Relative adhesion ratio indicates that the adhesion of H. py/ori in $100 \mathrm{mg} / \mathrm{dL}$ of glucose serve as the reference, and the bacterial adhesion value in 150 and $200 \mathrm{mg} / \mathrm{dL}$ of glucose was divided by the value of reference. *indicated a significant difference between the treatment of different glucose concentrations (paired $t$ test, $p<0.05$ ).

\section{Discussion}

The identification of cofactors involved in $H$. pylorirelated gastric carcinogenesis is important due to the fact that not all $H$. pylori-infected patients developing gastric cancer. Higher fasting plasma glucose levels in H. pylori-seropositive patients significantly increased the risk of gastric cancer, suggesting that hyperglycemia may contribute to $H$. pylori-related gastric carcinogenesis $[7,8]$. The possible mechanisms by which hyperglycemia affects $H$. pylori-related gastric carcinogenetic process include: (1) glucose itself may activate $\mathrm{Wnt} / \beta$-catenin pathway or increase reactive oxygen species to induce DNA damage, which contribute to $H$. pylori pathogenic effect; (2) hyperglycemia influences $H$. pylori and $H$. pylori-related infectious status or stimulates its carcinogenic effect. However, at present, the detailed mechanism is remains unclear. In the present study, we demonstrate that higher glucose could maintain $H$. pylori growth and viability after $48 \mathrm{~h}$. $H$. pylori adhesion and CagA expression was further increased to facilitate the enhancement of cell-associated CagA and phosphorylated CagA in higher glucose conditions. These results support the second possible mechanism.

Reynolds and Pann demonstrated that glucose enhances H. pylori growth in a defined medium [28]. Albertson et al. [29] found that the presence of glucose did not show growth enhancement on $H$. pylori. This discrepancy may be due to strain variations and detection methods utilized. In the study of Albertson et al, growth and yield of $H$. pylori (numbers of CFU per milliliter) was shown to have no difference by adding 0.2 or $1.0 \%$ glucose $(200$ or $1000 \mathrm{mg} / \mathrm{dL}$ ) to the defined medium supplemented with $0.5 \%$ BSA. This could be due to the high bacterial density $\left(10^{7} \mathrm{CFU} / \mathrm{ml}\right)$ at the beginning of inoculation. Glucose was rapidly consumed and could not provide for further growth because of growth and yield only increased before $20 \mathrm{~h}$. In our study, we found that higher glucose concentrations $(200 \mathrm{mg} / \mathrm{dL})$ could keep up the growth curve detected by OD at $600 \mathrm{~nm}$ after $48 \mathrm{~h}$ of inoculation (Figure 1A and B). Moreover, the viability of $H$. pylori at the same concentration of glucose was obviously higher than that of 100 or $150 \mathrm{mg} / \mathrm{dL}$ at $72 \mathrm{~h}$ 


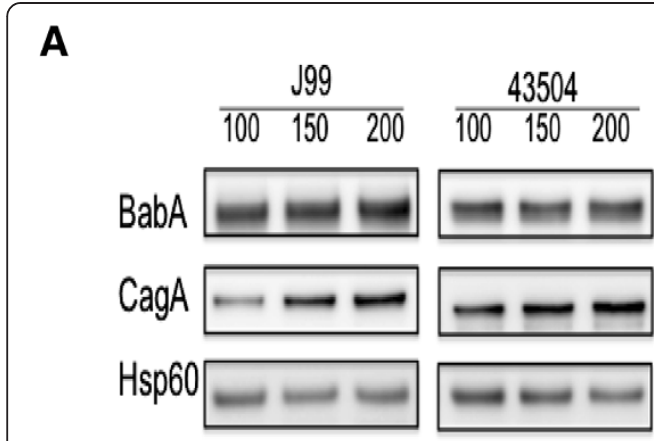

B
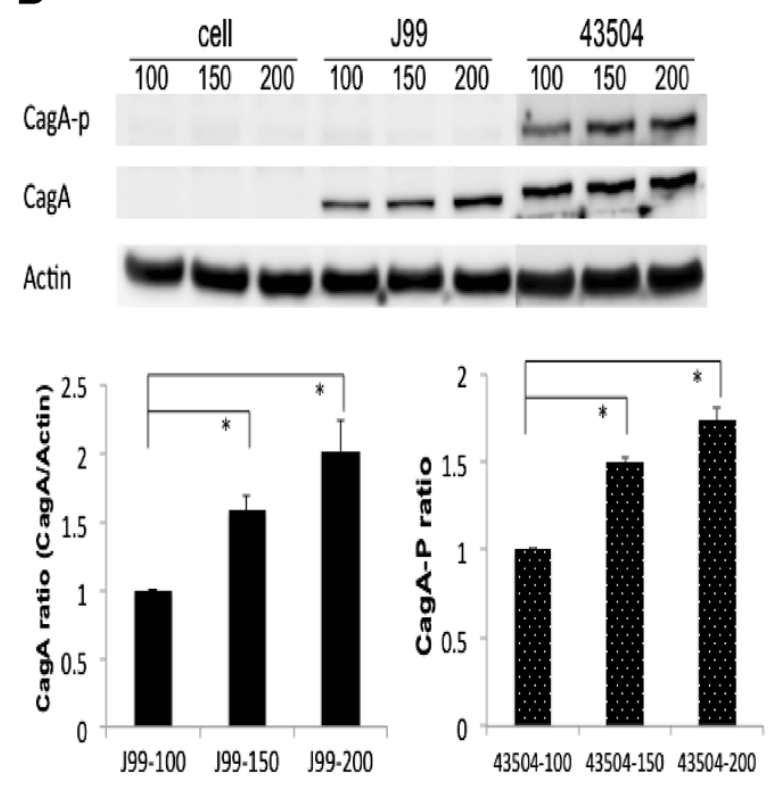

Figure 3 Figure $3 \mathrm{H}$. pylori CagA and phosphorylated CagA increased in higher glucose concentration. (A) BabA and CagA expression of $\mathrm{H}$. pylori grown in three glucose concentrations. (B) The level of cell-associated CagA and phosphorylated CagA after H. pylori infecting AGS cells for $4 \mathrm{~h}$. Thee glucose concentrations were 100, 150 and $200 \mathrm{mg} / \mathrm{dL}$, respectively. *indicated a significant difference between the treatment of different glucose concentrations (paired $t$ test, $p<0.05$ ).

(Figure 1C and D). This data was supported by Albertson et al. [29]. They found that viability of $H$. pylori in the presence of glucose obviously retains after inoculation of 2 days, as compared to non-glucose addition. We further provide the result that glucose can enhance $H$. pylori viability with a dose-dependent effect at $72 \mathrm{~h}$ (Figure $1 \mathrm{C}$ and $\mathrm{D}$ ).

Whether or not an infection rate of $H$. pylori is higher in DM patients remains controversial. Some studies report that the prevalence of $H$. pylori in DM patients shows no significant difference as compared to controls [30,31]. In these articles, only the $H$. pylori infection rate was studied, but no more detailed analysis was conducted to trace the H. pylori density-related histology or virulence severity. Our study revealed that $H$. pylori adhesion was enhanced in higher glucose concentrations (Figure $2 \mathrm{~A}$ and $\mathrm{B}$ ). We provide data supporting the possibility that glucose may influence $H$. pylori density colonizing on the gastric epithelium. H. pylori colonization could further interact with gastric epithelium to induce gastric inflammation [32,33]. In diabetic patients, $H$. pylori infection was significantly associated with chronic gastritis, but not in dyspeptic patients [34].

This study should be considered as being original to illustrate that bacterial adhesion to gastric epithelial cells can be enhanced by a higher glucose condition. H. pylori growth in 100,150 and $200 \mathrm{mg} / \mathrm{dL}$ of glucose is shown to have an increasing trend after being added to AGS cells pretreated with contrary concentrations of glucose (Figure 2C and D). It indicates that bacterial factors may play a more important role in increasing adhesion. When we analyzed BabA expression of $H$. pylori growth in three different glucose conditions, it did not show significant differences (Figure 3A). However, CagA expression was elevated as $H$. pylori growth in the increasing concentration of glucose (Figure 3A). Cell-associated CagA of strain 199 and phosphorylated CagA of strain 43504 were significantly increased in higher glucose conditions of infection (150 and $200 \mathrm{mg} / \mathrm{dL}$ ) (Figure 3B). Therefore, the enhancement of cell-associated or phosphorylated CagA could be due to the elevated adhesion ability and CagA expression of $H$. pylori in higher glucose conditions (Figures 2A, B and 3A).

Ishijima et al. [33] demonstrated that BabA-mediated adherence increases the effectiveness of $H$. pylori type IV secretion activity, implying the promoting role of $H$. pylori adhesion in type IV secretion activity. Moreover, phosphorylation of CagA is essential for induction of gastrointestinal neoplasm in transgenic mice [35]. Due to the elevated phosphorylated CagA in higher glucose conditions, it may further contribute to facilitate a more evident gastric carcinogenesis in the H. pylori-infected DM patients.

\section{Conclusions}

In summary, we provide in vitro evidence that H. pylori growth, viability, CagA and phosphorelated CagA after infecting gastric epithelial cells could be enhanced in higher glucose condition, supporting that hyperglycemia could be a cofactor to increase a risk of $H$. pylori related gastric carcinogenesis. The evidence would indicate that it is important to conduct large-scale $H$. pylori screening and eradication to control the increased risk of gastric cancer for DM patients, especially in high $H$. pylori-infected or gastric cancer prevalent countries.

\section{Competing interests}

The authors declare that they have no competing interests.

\section{Authors' contributions}

SMS conducted the experiment and prepared the draft. SBS developed the study concept and refined the draft. CH, KCY, YYJ and WJJ assisted with the gathering of data. All authors have read and approved the final manuscript. 


\section{Acknowledgement}

This study was supported by grants 101-2314-B- 006-016-MY3 from the National Scientific Council, and DOH102-TD-C-111-003 from Department of Health, Taiwan.

\section{Author details}

${ }^{1}$ Institute of Basic Medical Sciences, College of Medicine, National Cheng-Kung University, Tainan, Taiwan. ${ }^{2}$ Department of Medicine, College of Medicine, National Cheng-Kung University, Tainan, Taiwan. ${ }^{3}$ Department of Pediatrics, College of Medicine, National Cheng-Kung University, Tainan, Taiwan. ${ }^{4}$ Department of Medical Laboratory Science and Biotechnology, College of Medicine, National Cheng-Kung University, Tainan, Taiwan. ${ }^{5}$ Department of Internal Medicine, National Cheng Kung University Hospital, College of Medicine, National Cheng Kung University, \#138 Sheng Li Road, Tainan, Taiwan.

Received: 8 August 2014 Accepted: 29 September 2014

Published online: 09 October 2014

\section{References}

1. Price AB, Levi J, Dolby JM, Dunscombe PL, Smith A, Clark J, Stephenson ML: Campylobacter pyloridis in peptic ulcer disease: microbiology, pathology, and scanning electron microscopy. Gut 1985, 26:1183-1188.

2. Rauws EA, Langenberg W, Houthoff HJ, Zanen HC, Tytgat GN: Campylobacter pyloridis-associated chronic active antral gastritis. A prospective study of its prevalence and the effects of antibacterial and antiulcer treatment. Gastroenterology 1988, 94:33-40.

3. Parsonnet J, Friedman GD, Vandersteen DP, Chang Y, Vogelman JH, Orentreich N, Sibley RK: Helicobacter pylori infection and the risk of gastric carcinoma. N Engl J Med 1991, 325:1127-1131.

4. Ataseven H, Demir M, Gen R: Effect of sequential treatment as a first-line therapy for Helicobacter pylori eradication in patients with diabetes mellitus. South Med J 2010, 103:988-992.

5. Zhou X, Zhang C, Wu J, Zhang G: Association between Helicobacter pylori infection and diabetes mellitus: a meta-analysis of observational studies. Diabetes Res Clin Pract 2013, 99:200-208.

6. Demir M, Gokturk HS, Ozturk NA, Serin E, Yilmaz U: Efficacy of two different Helicobacter pylori eradication regimens in patients with type 2 diabetes and the effect of Helicobacter pylori eradication on dyspeptic symptoms in patients with diabetes: a randomized controlled study. Am J Med Sci 2009, 338:459-464.

7. Yamagata H, Kiyohara Y, Nakamura S, Kubo M, Tanizaki Y, Matsumoto T, Tanaka K, Kato I, Shirota T, lida M: Impact of fasting plasma glucose levels on gastric cancer incidence in a general Japanese population: the Hisayama study. Diabetes Care 2005, 28:789-794.

8. Marimuthu S, Vijayaragavan P, Moysich KB, Jayaprakash V: Diabetes mellitus and gastric carcinoma: is there an association? J Carcinog 2011, 10:30.

9. Sheu BS, Yang HB, Yeh YC, Wu JJ: Helicobacter pylori colonization of the human gastric epithelium: a bug's first step is a novel target for us. J Gastroenterol Hepatol 2010, 25:26-32.

10. Amieva MR, El-Omar EM: Host-bacterial interactions in Helicobacter pylori infection. Gastroenterology 2008, 134:306-323.

11. Maeda S, Mentis AF: Pathogenesis of Helicobacter pylori infection. Helicobacter 2007, 12(Suppl 1):10-14.

12. Ilver D, Arnqvist A, Ogren J, Frick IM, Kersulyte D, Incecik ET, Berg DE, Covacci A, Engstrand L, Borén T: Helicobacter pylori adhesin binding fucosylated histoblood group antigens revealed by retagging. Science 1998, 279:373-377.

13. Mahdavi J, Sondén B, Hurtig M, Olfat F, Forsberg L, Roche N, Angstrom J, Larsson T, Teneberg S, Karlsson KA, Altraja S, Wadström T, Kersulyte D, Berg DE, Dubois A, Petersson C, Magnusson KE, Norberg T, Lindh F, Lundskog BB, Arnqvist A, Hammarström L, Borén T: Helicobacter pylori SabA adhesin in persistent infection and chronic inflammation. Science 2002, 297:573-578.

14. Rad R, Gerhard M, Lang R, Schöniger M, Rösch T, Schepp W, Becker I, Wagner H, Prinz C: The Helicobacter pylori blood group antigen-binding adhesin facilitates bacterial colonization and augments a nonspecific immune response. J Immunol 2002, 168:3033-3041.

15. Asahi M, Azuma $T$, Ito $S$, Ito $Y$, Suto $H$, Nagai $Y$, Tsubokawa $M$, Tohyama $Y$, Maeda S, Omata M, Suzuki T, Sasakawa C: Helicobacter pylori CagA protein can be tyrosine phosphorylated in gastric epithelial cells. J Exp Med 2000, 191:593-602.

16. Backert S, Ziska E, Brinkmann V, Zimny-Arndt U, Fauconnier A, Jungblut PR, Naumann M, Meyer TF: Translocation of the Helicobacter pylori CagA protein in gastric epithelial cells by a type IV secretion apparatus. Cell Microbiol 2000, 2:155-164.

17. Odenbreit S, Püls J, Sedlmaier B, Gerland E, Fischer W, Haas R: Translocation of Helicobacter pylori CagA into gastric epithelial cells by type IV secretion. Science 2000, 287:1497-1500.

18. Stein M, Rappuoli R, Covacci A: Tyrosine phosphorylation of the Helicobacter pylori CagA antigen after cag-driven host cell translocation. Proc Natl Acad Sci U S A 2000, 97:1263-1268.

19. Higashi H, Tsutsumi R, Fujita A, Yamazaki S, Asaka M, Azuma T, Hatakeyama M: Biological activity of the Helicobacter pylori virulence factor CagA is determined by variation in the tyrosine phosphorylation sites. Proc Natl Acad Sci U S A 2002, 99:14428-14433.

20. Churin Y, Al-Ghoul L, Kepp O, Meyer TF, Birchmeier W, Naumann M: Helicobacter pylori CagA protein targets the c-Met receptor and enhances the motogenic response. J Cell Biol 2003, 161:249-255.

21. Higashi H, Nakaya A, Tsutsumi R, Yokoyama K, Fujii Y, Ishikawa S, Higuchi M, Takahashi A, Kurashima Y, Teishikata Y, Tanaka S, Azuma T, Hatakeyama M: Helicobacter pylori CagA induces Ras-independent morphogenetic response through SHP-2 recruitment and activation. J Biol Chem 2004, 279:17205-17216.

22. Mimuro H, Suzuki T, Tanaka J, Asahi M, Haas R, Sasakawa C: Grb2 is a key mediator of Helicobacter pylori CagA protein activities. Mol Cell 2002, 10:745-755

23. Tsutsumi R, Takahashi A, Azuma T, Higashi H, Hatakeyama M: Focal adhesion kinase is a substrate and downstream effector of SHP-2 complexed with Helicobacter pylori CagA. Mol Cell Biol 2006, 26:261-276.

24. Chocarro-Calvo A, Garcia-Martinez JM, Ardila-Gonzalez S, De la Vieja A, Garcia-Jimenez C: Glucose-induced beta-catenin acetylation enhances Wnt signaling in cancer. Mol Cell 2013, 49:474-486.

25. Chronopoulos A, Trudeau K, Roy S, Huang H, Vinores SA, Roy S: High glucose-induced altered basement membrane composition and structure increases trans-endothelial permeability: implications for diabetic retinopathy. Curr Eye Res 2011, 36:747-753.

26. Morss AS, Edelman ER: Glucose modulates basement membrane fibroblast growth factor-2 via alterations in endothelial cell permeability. J Biol Chem 2007, 282:14635-14644.

27. Sheu BS, Sheu SM, Yang HB, Huang AH, Wu JJ: Host gastric Lewis expression determines the bacterial density of Helicobacter pylori in babA2 genopositive infection. Gut 2003, 52:927-932.

28. Reynolds DJ, Penn CW: Characteristics of Helicobacter pylori growth in a defined medium and determination of its amino acid requirements. Microbiology 1994, 140:2649-2656.

29. Albertson N, Wenngren I, Sjostrom JE: Growth and survival of Helicobacter pylori in defined medium and susceptibility to Brij 78. J Clin Microbiol 1998, 36:1232-1235.

30. Ariizumi $K$, Koike $T$, Ohara $S$, Inomata $Y$, Abe $Y$, lijima K, Imatani A, Oka T, Shimosegawa T: Incidence of reflux esophagitis and $H$. pylori infection in diabetic patients. World J Gastroenterol 2008, 14:3212-3217.

31. Hsieh MC, Wang SS, Hsieh YT, Kuo FC, Soon MS, Wu DC: Helicobacter pylori infection associated with high $\mathrm{HbA1c}$ and type 2 diabetes. Eur J Clin Invest 2013, 43:949-956.

32. Nagai S, Mimuro H, Yamada T, Baba Y, Moro K, Nochi T, Kiyono H, Suzuki T, Sasakawa C, Koyasu S: Role of Peyer's patches in the induction of Helicobacter pylori-induced gastritis. Proc Natl Acad Sci U S A 2007, 104:8971-8976.

33. Ishijima N, Suzuki M, Ashida H, Ichikawa Y, Kanegae Y, Saito I, Boren T, Haas R, Sasakawa C, Mimuro H: BabA-mediated adherence is a potentiator of the Helicobacter pylori type IV secretion system activity. J Bio/ Chem 2011, 286:25256-25264.

34. Marrollo M, Latella G, Melideo D, Storelli E, lannarelli R, Stornelli P, Valenti M, Caprilli R: Increased prevalence of Helicobacter pylori in patients with diabetes mellitus. Dig Liver Dis 2001, 33:21-29.

35. Ohnishi N, Yuasa H, Tanaka S, Sawa H, Miura M, Matsui A, Higashi H, Musashi M, Iwabuchi K, Suzuki M, Yamada G, Azuma T, Hatakeyama M: Transgenic expression of Helicobacter pylori CagA induces gastrointestinal and hematopoietic neoplasms in mouse. Proc Natl Acad Sci U S A 2008, 105:1003-1008.

doi:10.1186/s12929-014-0096-9

Cite this article as: Sheu et al:: Higher glucose level can enhance the $H$. pylori adhesion and virulence related with type IV secretion system in AGS cells. Journal of Biomedical Science 2014 21:96. 